\title{
Corn silage with and without enzyme-bacteria inoculants on performance, carcass characteristics and meat quality in feedlot finished crossbred bulls
}

\author{
Carlos Alberto Fugita ${ }^{1}$, Ivanor Nunes do Prado ${ }^{2}$, Clóves Cabreira Jobim², Fernando \\ Zawadzki $^{1}$, Maribel Velandia Valero ${ }^{1}$, Maria Carla de Oliveira Pires ${ }^{3}$, Rodolpho Martin do \\ Prado $^{3}$, Mônica Chaves Françozo ${ }^{3}$
}

\footnotetext{
1 Programa de Pós-Graduação em Zootecnia - Universidade Estadual de Maringá. Av. Colombo, 5790-87020-900 - Maringá, Paraná, Brazil.

2 Departamento de Zootecnia - Universidade Estadual de Maringá. Bolsista 1A de Produtividade em Pesquisa do CNPq.

${ }^{3}$ Graduação em Zootecnia - Departamento de Zootecnia - Universidade Estadual de Maringá.
}

\begin{abstract}
Two height cuttings of corn silage with or without enzyme inoculants were evaluated for 68 days on performance, carcass characteristics, meat quality and chemical composition of the Longissimus muscle in crossbred bulls (F1 - 1/2 Nellore vs. $1 / 2$ Angus) finished in feedlot. Thirty-two 20-month-old bulls, with initial average weight of $374 \pm 25 \mathrm{~kg}$, were kept in individual pens $\left(10 \mathrm{~m}^{2}\right)$. Diets consisted of $50 \%$ roughage and $50 \%$ concentrate, with an expected $1.80 \mathrm{~kg} / \mathrm{day}$ weight gain. The experimental design with four diets and eight replications was completely randomized. Different cutting heights, low $(25 \mathrm{~cm})$ and high $(45 \mathrm{~cm})$, with or without enzyme inoculants, were studied. Live weight, average daily gain, feed intake, feed efficiency, carcass characteristics, muscle, fat and bone percentages at the $11^{\text {th }}$ and $12^{\text {th }}$ ribs, chemical composition of the Longissimus muscle, sum of saturated, mono-unsaturated, poly-unsaturated fatty acids, $n$ - 3 fatty acids, n-6 fatty acids, and the poly-unsaturated:saturated and n-6:n-3 relations were determined. Cutting height of silage corn and the use of inoculants did not affect final live weight, average daily gain, feed intake, alimentary efficiency of dry matter, carcass characteristics, meat quality, chemical composition of the Longissimus muscle or fatty acid profile. High cutting of silage corn (45 cm above the ground) and the use of inoculants are not necessary in the case of cattle finished in feedlot, with $1.8 \mathrm{~kg}$ daily gain.
\end{abstract}

Key Words: feed efficiency, feed intake, finishing system, forage conservation, human health, meat quality

\section{Introduction}

Brazil has the biggest cattle population on the world (173 millions) and a production of 7.6 million tons of carcass per year (Anualpec, 2009), with an export of approximately $23 \%$ of this amount. Although in Brazil most beef cattle (90\%) is finished in pasture system (Anualpec, 2009), forage production depends on seasonality, which modifies its quality and quantity (Moreira et al., 2003; Aricetti et al., 2008). This means that in certain periods of the year (winter) pasture supplements are required (Reis et al., 2009). Genetic improvement in beef cattle and in beef productivity and quality (Abrahão et al., 2005; 2006; Maggioni et al., 2009; Rotta et al., 2009b) has determined higher nutritional requirements. The new beef production model is rounded up with cattle finished in feedlot (Maggioni et al., 2009; Prado et al., 2008b,c; Prado et al., 2009a; Rotta et al., 2009b) although conserved forage is required for feedlot.

Beef quality is determined by several factors, feed in particular (Rotta et al., 2009b), and its effects are related to the carcass' chemical composition. Since beef quality is associated with fat deposits, the composition of fatty acids in beef may be modified through feed given to the animals (Webb, 2006; Rotta et al., 2009b).

In Brazil, corn is the most used culture in silage since it is of excellent quality, with a high production of dry matter per area unit. Harvested corn with higher cuttings has been indicated as an alternative for higher-quality forage (Restle et al., 2002).

On the other hand, enzyme-bacterial inoculants in silage may improve the fermentation standard with a subsequent improvement of performance. Whereas bacterial inoculants promote and increase fermentation speed and standard through an increase in lactic acid bacteria population, enzyme inoculants act on the cell wall and make a higher quantity of fermentable sugars available, with a consequent improvement of silage digestibility.

This study was carried out to evaluate performance, carcass characteristics and chemical composition of the Longissimus muscle of beef cattle fed on corn silage with cuttings at two heights to which enzyme-bacterial inoculants were added. 


\section{Material and Methods}

Thirty-two 20-month-old crossbred bulls (F1-1/2 Nellore vs. $1 / 2$ Angus), average weight of $374 \pm 25 \mathrm{~kg}$, were used in the current assay. Prior to the start of the experiment, bulls had been placed in a pasture (Cynodon spp. $c v$. Tifton 85) without any supplements. Animals were randomly kept in $10-\mathrm{m}^{2}$ individual, partially covered pens with concrete floor, furnished with 250-L drinking troughs and concrete $2 \times 0.4 \times 0.5-\mathrm{m}$ feeding troughs. Bulls were vaccinated for foot-and-mouth disease, dewormed and distributed in a completely randomized design. Feed formulation and quantity given daily to the animals followed NRC (2000) recommendations, so that a $1.80 \mathrm{~kg} /$ day weight increase could be achieved (Table 1).

Full iso-energetic and iso-protein diets, comprising $50 \%$ roughage and $50 \%$ concentrate, were given at $8 \mathrm{~h}$ and $16 \mathrm{~h}$. However, fiber rates of diets with corn silage cut $25 \mathrm{~cm}$ above the ground were higher due to a greater participation of the corn lower section (stalk).

The hybrid corn Dekalb 789 was planted in a 7-ha area with a population of 60 thousand plants/ha and a $0.9-\mathrm{m}$ spacing between rows. Seeding took place in November 2007 and harvest occurred in February 2008. Forage was harvested with silage machine JF92Z10, regulated for 10-mm cutting. Silage was stored in four lined trench-type silos, $3.40 \times 1.10 \times\left(3.74 \mathrm{~m}^{2}\right) \times 13 \mathrm{~m}$, with a total volume of $48.62 \mathrm{~m}^{3}$. Approximately $26 \mathrm{t}$ of silage were stored in each silo.

Silage was divided into four treatments: 25 -cm cutting height without inoculants; 45 -cm cutting height without inoculants; 25 -cm cutting height with inoculants; $45-\mathrm{cm}$ cutting height with inoculants. Lactobacillus plantarum, Enterococcus faecium, concentration $1 \times 10^{11} \mathrm{ufc} / \mathrm{g}$ of product, Pediococcus acidilactici, concentration $1 \times 10^{11} \mathrm{ufc} / \mathrm{g}$, coupled to amylase, celulase and hemicellulose enzyme composed the inoculants Maize - All ${ }^{\circledR}$ employed. Inoculants were applied by shoulder sprayer according to manufacturer, or rather, at $250 \mathrm{~g}$ for $50 \mathrm{t}$ of forage, with dilution of $250 \mathrm{~g}$ into $50 \mathrm{~L}$ of water. After silage had been stored for 150 days, silos were opened for evaluation.

Average daily weight gain was evaluated when beef bulls were weighted after a 16-h fast (solid food) at the start of the experiment and then at every 28 days. Bulls' final weight was determined on the $68^{\text {th }}$ day. The last period comprised 12 days since the animals had reached the expected final weight $(500 \mathrm{~kg})$. Daily weighting of feed provided and feed leftovers, estimated at $5 \%$ of feed provided, estimated food intake. Average daily gain (ADG) was calculated by the difference between the initial live weight (ILW) and the final live weight (FLW), divided by the number of trial days (68).

At the end of the experiment, crossbreeds were slaughtered at a commercial abattoir $20 \mathrm{~km}$ away from Maringá, Paraná after a solid feed fast according to cattle finishing routine in Brazil.

Feed efficiency of dry matter (FE) was calculated by the ratio between intake and animal performance according to the equation: $\mathrm{FE}=(\mathrm{IDM} / \mathrm{ADG})$.

The intake of dry matter (DM), organic matter (OM), mineral matter $(\mathrm{MM})$, crude protein $(\mathrm{CP})$ and neutral detergent fiber (NDF) of intake of feed and leftovers were determined according to methodology described by Silva \& Queiroz(2002).

After finishing, carcasses were divided medially through the sternum and vertebral column. The two similar halves were weighed to determine the weight of the hot

Table 1 - Feed and diet composition

\begin{tabular}{|c|c|c|c|c|c|c|c|c|c|c|}
\hline \multirow[b]{2}{*}{ Ingredients } & \multicolumn{9}{|c|}{ DM, \% } & \multirow[b]{2}{*}{ Diet, \% } \\
\hline & DM & $\mathrm{CP}$ & $\mathrm{OM}$ & ASH & $\mathrm{EE}$ & $\mathrm{NDF}$ & $\mathrm{ADF}$ & NFC & TDN & \\
\hline LSI & 32.55 & 7.48 & 96.58 & 3.42 & 2.61 & 47.26 & 27.52 & 39.24 & 63.29 & 50.00 \\
\hline HSI & 31.05 & 7.35 & 96.51 & 3.49 & 2.77 & 43.47 & 26.65 & 42.91 & 63.18 & 50.00 \\
\hline HW I & 31.35 & 6.80 & 96.66 & 3.34 & 2.70 & 46.49 & 26.46 & 40.67 & 63.87 & 50.00 \\
\hline Corn & 88.00 & 8.86 & 98.92 & 1.08 & 3.50 & 20.29 & 7.00 & 66.27 & 87.89 & 40.18 \\
\hline Soybean & 88.00 & 49.84 & 93.29 & 6.71 & 0.50 & 15.51 & 9.50 & 27.44 & 81.54 & 8.93 \\
\hline \multicolumn{11}{|l|}{ Total diet } \\
\hline LSI & 47.55 & 11.75 & 96.65 & 3.34 & 2.76 & 33.17 & 17.42 & 48.98 & 74.05 & \\
\hline LW I & 47.06 & 11.69 & 96.77 & 3.22 & 2.81 & 33.99 & 16.79 & 48.17 & 73.42 & \\
\hline HSI & 45.93 & 11.68 & 96.62 & 3.38 & 2.84 & 31.27 & 16.99 & 50.83 & 75.50 & \\
\hline HWI & 46.26 & 11.41 & 96.70 & 3.30 & 2.80 & 32.78 & 16.89 & 49.71 & 74.34 & \\
\hline
\end{tabular}

$\mathrm{DM}=$ dry matter; $\mathrm{CP}=$ crude protein $; \mathrm{OM}=$ organic matter; $\mathrm{NDF}=$ neutral detergent fiber; $\mathrm{ADF}=$ acid detergent fiber; $\mathrm{NFC}=$ non-fibrous carbohydrates; $\mathrm{TDN}=$ total digestible nutrients, LSI = corn silage with low cutting and without inoculants; LWI = low cutting with inoculants; HSI $=$ high cutting without inoculants; HWI $=$ high cutting with inoculants. 
carcass. Hot carcass dressing was determined by the ratio between the weight of the hot carcass and final live weight multiplied by 100 .

Carcasses were then identified and conditioned in freezers at a temperature below $2{ }^{\circ} \mathrm{C}$, and kept for $24 \mathrm{~h}$.

Carcass physical factors, such as conformation, length of carcass, length of leg and thickness of cushion were evaluated after the chilling period. Cover fat thickness, Longissimus muscle area, color, texture and marbling were determined from the Longissimus muscle.

Carcass conformation was determined subjectively by taking into consideration muscle development (cover fat excluded), according to methodology by Müller (1980).

Carcass length, the distance between the pubis bone edge and the medial cranial edge of the first rib, was calculated by tape measure.

Length of leg, or rather, the distance, in $\mathrm{cm}$, between the edge of the pubis bone and a mid-point of the tarsus articulation bones, was measured by a wooden compass. The distance was then measured by tape.

Using the above-mentioned compass, cushion thickness was calculated by tape-measuring the distance between the lateral and medial section of the cushion upper part.

Cover fat thickness was estimated as from the left side of the carcass by exposing the Longissimus muscle at the region between the $12^{\text {th }}$ and $13^{\text {th }}$ rib, through the mean of three equidistant points, by a precision caliper.

The Longissimus muscle area was retrieved from the longissimus muscle between the $12^{\text {th }}$ and $13^{\text {th }}$ ribs. The muscle was traced on vegetal paper and the area was measured by a planimeter.

Color of the Longissimus muscle was calculated after a 30-min exposure to oxygen, according to score scale by Müller (1980). Color was determined by a single evaluation to avoid subjective interpretations in the process.

Determined by a subjective evaluation of the Longissimus muscle according to score scale by Müller (1980), texture comprised the size of fascicles (beef granules) in the Longissimus muscle.

Marbling features (amount of fat within the Longissimus muscle) were calculated by a single factor, according to score scale by Müller (1980).

Measurement of muscle, fat and bone, percentages in the carcass comprised a section of the Longissimus muscle corresponding to the $10^{\text {th }}, 11^{\text {th }}$ and $12^{\text {th }}$ rib, with cuts following Hankins \& Howe (1946) and modified by Müller (1980). Muscle, fat and bone were separated and individually weighed. Percentages of each informed the regression equations by Müller et al. (1973) and described by transforming data corresponding to the $9^{\text {th }}, 10^{\text {th }}$ and $11^{\text {th }}$ ribs:
$\% \mathrm{M}=6.292+0.910 \times 2$

$\% \mathrm{~F}=1.526+0.913 \mathrm{X} 3$

$\% \mathrm{~B}=2.117+0.860 \mathrm{X} 1$

where X1 represents bone, muscle and fat percentages, respectively. Regression equations were informed by the percentages of the $9^{\text {th }}, 10^{\text {th }}$ and $11^{\text {th }}$ ribs, according to Hankins \& Howe (1946), below, and thus the percentages for bone, muscle and fat in the carcasses under analysis: $\% \mathrm{M}=15.56+0.81 \mathrm{M}$

$\% \mathrm{~F}=3.06+0.82 \mathrm{G}$

$\% \mathrm{~B}=4.30+0.61 \mathrm{O}$

where $\mathrm{M}, \mathrm{F}$ and B stand for muscle, fat and bone, respectively, as found by equations suggested by Müller et al. (1980).

After thawing at room temperature, the fat-less beef samples were ground so that moisture and ash rates could be determined, according to methodology by AOAC (1980). Whereas crude protein rates were calculated by the Kjeldahl method (Cunnif, 1998), total lipids were determined according to Bligh \& Dyer (1959), with a mixture of chloroform and methanol. Extraction of total cholesterol was obtained by method described by Al Hasani et al. (1993) and its rate was analyzed with a Shimadzu 14-A gas chromatograph with a flame ionization detector and a cast silica capillary column ( $25 \mathrm{~cm}$-length; 0.25 -mm inner diameter and $0.20-\mu \mathrm{m}$ SE-30). Injector, detector and column temperatures were respectively 260,300 and $300^{\circ} \mathrm{C}$. Gas flows were: $1.5 \mathrm{~mL} / \mathrm{min}$ forcarriergas $\left(\mathrm{H}_{2}\right) ; 25 \mathrm{~mL} /$ min formake-up gas $\left(\mathrm{N}_{2}\right) ; 300 \mathrm{~mL} / \mathrm{min}$ for synthetic air and $30 \mathrm{~mL} / \mathrm{min}$ for flame $\mathrm{H}_{2}$. Peak areas were determined by advanced DataApex Clarity Lite, and the identification of total cholesterol was done by comparing retention periods by Sigma (USA) standards. Calculation of cholesterol samples were analyzed after their verification by the linear method. Standard solutions Sigma (USA) were prepared at concentrations $0.0 ; 0.4 ; 0.8 ; 1.6$ and $2.0 \mathrm{mg} \mathrm{mL}^{-1}$, with $0.2 \mathrm{mg} \mathrm{mL}^{-1} 5 \alpha$-colestan (Sigma, USA) in all of them, and then analyzed. Ratios of cholesterol and $5 \alpha$-colestan areas were compared with cholesterol concentration for injected volumes $0.0 ; 2.0 ; 3.0 ; 4.0 ; 5.0 \mu \mathrm{L}$. Cholesterol in $\mathrm{mg}$ $100 \mathrm{~g}^{-1}$ was analyzed by the curve obtained, whereas the extraction and obtaining of fatty acid esters were done according to ISO (1978). Methyl esters of fatty acids were analyzed by gas chromatograph Shimadzu 14-A, with flame ionization detector and cast silica capillary column (100-m length, $0.25-\mathrm{mm}$ inner diameter and $0.20-\mu \mathrm{m}$ CP-Sil 88 , ChromPack). Gas flows were $1.2 \mathrm{~mL} / \mathrm{min}$ for carrier gases $\mathrm{H}_{2}$, $30 \mathrm{~mL} / \mathrm{min}$ for auxiliary gas $\mathrm{N}_{2}$, and 30 and $300 \mathrm{~mL} / \mathrm{min}$, respectively for $\mathrm{H}_{2}$ flame gases and synthetic air. Whereas injector and detector temperatures were respectively 220 and $245^{\circ} \mathrm{C}$, column temperature reached $140{ }^{\circ} \mathrm{C}$ for $5 \mathrm{~min}$; then raised to $225^{\circ} \mathrm{C}$ at the rate of $4{ }^{\circ} \mathrm{C} / \mathrm{min}$. Ratio of sample 
division was 1/100 and peak areas were determined by advanced DataApex Clarity Lite. They were identified by comparing retention times of methyl esters of fatty acids Sigma (USA).

The experiment comprised four diets and eight repetitions. Results underwent variance analysis with SAS statistical package (Statistical Analysis System, version 8.1) and data were analyzed according to $2 \times 2$ factor. However, no interaction was found between the presence or absence of inoculants and cutting height of corn silage. Comparison of means was undertaken by the Tukey test.

\section{Results and Discussion}

Cutting height of corn silage, with or without inoculants, had no effect $(\mathrm{P}>0.05)$ on FLW and ADG in crossbred bulls finished in feedlot (Table 2).

Mean FLW and ADG were respectively $500 \mathrm{~kg}$ and $1.85 \mathrm{~kg}$. Restle et al. (2002) failed to report any difference for ADG in 12-month-old feedlot Braford steers fed on corn silage with two cutting heights (16 and $46 \mathrm{~cm}$ ). Posteriorly, Neumann et al. (2007) did not report any difference for ADG $(1.5 \mathrm{~kg})$ in feedlot Charolais bulls fed on corn silage with two cutting heights ( 15 and $39 \mathrm{~cm}$ ).

Final live weight and ADG were high in these crossbreeds since, as a rule, the weight of 20-24-month-old crossbred bulls, finished in feedlot, is approximately $470 \mathrm{~kg}$ (Prado et al., $2008 \mathrm{~b}$ ), with an average daily weight gain of $1.50 \mathrm{~kg}$ (Abrahão et al., 2005). High FLW and ADG may be due to the (non-castrated) crossbreed sires, which require high weight for finishing so that market minimum requirements in cover fat scores ( $3 \mathrm{~mm}$ and over) are complied with. Their sexual conditions may partly explain the high performance of the crossbreeds (Rotta et al., 2009b) owing to hormones (testosterone) secreted by the animals. Testosterone production triggers Growth Hormone (GH) secretion, which determines a greater deposit of muscle tissues and allow higher performance of the animals(Lee et al., 1990). Moreover, crossbred bulls (F1-1/2 Nelore vs. 1/2 Angus) are finished with a high weight so that finishing degree and proper conformation are obtained. High performance may be also explained by high rates in the crude protein in the diet (11.6\%) and energy (74\% of TDN). The NRC (2000) suggests a diet with $12 \% \mathrm{CP}$ and $74 \% \mathrm{TDN}$ so that animals may have an approximate daily gain of $1.80 \mathrm{~kg} /$ day. Bulls derived from European vs. Zebus industrial crossings have high ADG (Abrahão et al., 2005; Maggioni et al., 2009). Similarly, animals finished in a short period of time (56 days) have high ADG (Dian et al., 2009), partly due to the compensatory gain during the first 30 days of feedlot.

Dry matter intake (DMI $-\mathrm{kg} /$ day), the intake of dry matter as a ratio of live weight (DMI/LW, \%), of crude protein, organic matter and neutral detergent fiber were not affected $(\mathrm{P}>0.05)$ by cutting height of corn silage and inoculants addition (Table 2). Mean intake of dry matter respectively amounted to $10.4 \mathrm{~kg} /$ day and to $2.4 \%$ of LW. Restle et al. (2002) reported mean DMI rates of $7.31 \mathrm{~kg} /$ day and of $2.53 \%$ of LW for crossbred bulls fed on corn silage with different cutting heights $(50 \%$ roughage $+50 \%$ concentrates). Similarly, Neumann et al. (2007) failed to register influence of cutting height on DMI ( $\mathrm{kg} /$ day) or on LW percentage in crossbred bulls fed on a 63:37 roughage:concentrate ratio. Mean DMI was $2.4 \%$ of LW. Similar results were reported by Maggioni et al. (2009) in crossbreeds with average age of 20 months and $356 \mathrm{~kg}$ of initial live weight, fed on 44:56 of roughage (sorghum silage):concentrate ratio. As a rule, crossbred bulls with weight gain between 1.5 and $1.8 \mathrm{~kg} /$ day, finished in feedlot, and fed on balanced diets of protein (12\%) and energy (72\%) have DMI ranging between 2.2 and 2.7\% LW (Abrahão et al., 2005; Maggioni et al., 2009). Nutrient balanced diets do not generally alter ruminating

Table 2 - Performance and feed intake of crossbred bulls fed on corn silage cuttings at different heights $(25 \mathrm{vs} .45 \mathrm{~cm})$, with or without inoculants

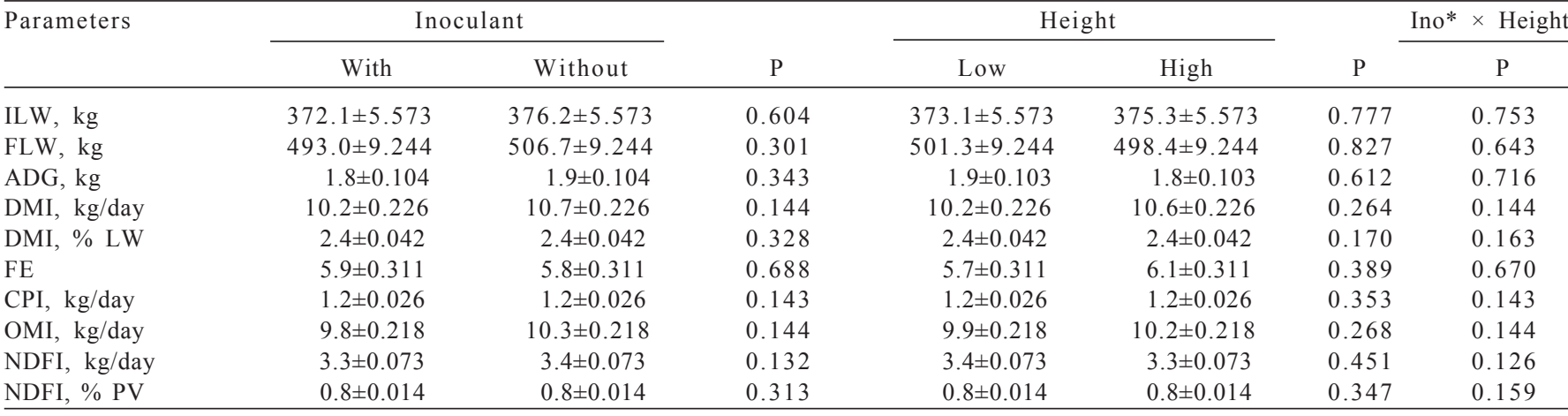

$\mathrm{ILW}=$ initial live weight; FLW = final live weight; $\mathrm{ADG}=$ average daily gain; $\mathrm{DMI}=$ dry matter intake; DMI $=$ dry matter intake as a ratio of live weight; $\mathrm{FE}=$ feed efficiency, $\mathrm{CPI}=$ crude protein intake; OMI = organic matter intake; NDFI = neutral detergent fiber intake; NDFI = neutral detergent fiber as a ratio of live weight; $\mathrm{LW}=$ live weight.

*Inoculant. 
conditions (Giger-Reverdin et al., 2002). There was no difference $(\mathrm{P}>0.05)$ between cutting height and inoculants for the feed efficiency of dry matter ( $\mathrm{kg}$ of DM/day for each $\mathrm{kg}$ of ADG). Since the mean feed efficiency was 5.9, these results were similar to those (5.7) obtained by Restle et al. (2002) in young steers fed on hybrid corn silage in two cutting heights (20 and $42 \mathrm{~cm}$ ). However, Neumann et al. (2007) reported similar feed efficiency for crossbred bulls fed on corn silage harvested at a height of $15 \mathrm{~cm}(6.2)$ and $38 \mathrm{~cm}$ (5.7). Efficiency of dry matter (5.9) may be due to the genetic degree of the animals ( $\mathrm{F} 1-1 / 2$ Nellore $v$ s. $1 / 2$ Angus), formulated $\operatorname{diet}$ (high protein rate $-12 \%$ and energy $-74 \%$ TDN), feedlot time (64 days) and animal gender (bulls). A good feed efficiency is reported in animals derived from industrial crossings between Bos taurus taurus vs. Bos taurus indicus (Prado et al., 2003) due to selection of bulls and heterosis effects, especially in the first generation (Perotto et al., 2000). High crude protein rate and energetic density improved feed efficiency of young bulls (NRC, 2000). Besides, a short feedlot period may have also been a factor in feed efficiency since the compensatory gain during the first 30 days would not be diluted during a long feedlot period. Animals had an excellent feed efficiency during the compensatory gain, since they transformed most nutrients into muscle tissues, whose deposit is more efficient than that of the fat tissue. Feed efficiency in bulls may also be due to growth hormones, whose secretion is stimulated by testosterone and directly influences IGF-I activity (Lee et al., 1990).

Cutting height and inoculants did not influence $(\mathrm{P}>0.05)$ neutral detergent fiber intake (NDFI $-\mathrm{kg} /$ day) or its relationship with live weight (NDFI/LW, \%). Since INDF and LW were respectively $3.4 \% \mathrm{~g} /$ day and $0.77 \%$, data were similar to those reported by Prado et al. (2003) on the performance of feedlot crossbred bulls when the replacement of corn silage by pineapple industrial wastes silage at the ratio of $44 \%$ roughage and $56 \%$ concentrate was evaluated. Wu \& Roth (2006) reviewed the management of corn cutting height for ensilage and reported a 7 to $10 \%$ decrease in NDF rates due to cutting height. Low NDF rate in ensilage cutting at a lower height is due to the small participation of the plant stalk, which provides low NDF intake in crossbred bulls fed on this type of silage. However, decrease in NDF intake has not been reported in this research and is probably due to low diet rate.

Carcass weight and hot carcass dressing were not modified ( $\mathrm{P}>0.05$ ) by cutting height of corn silage coupled or not to inoculants (Table 3). Final high mean weight of hot carcass $(275 \mathrm{~kg})$ was determined by the crossbred bulls high final weight (Table 2). Cattle finished in feedlot and fed with a high protein-rich diet and high energetic density present high carcass weight (Abrahão et al., 2005; Dian et al., 2009; Maggioni et al., 2009). Neumann et al. (2008) reported similar rates for feedlot Charolais young steers fed on different corn silage cuttings at two plant heights $(15$ or $39 \mathrm{~cm})$ during silage. The rates abovementioned corroborate data by Maggioni et al. (2009) for crossbred cattle at the same age and with the same genetic grade to those in this experiment and which were fed at a relation of $44 \%$ roughage (sorghum silage):56\% concentrate. High rates obtained are commonly reported in cattle derived from industrial crossing and finished in feedlot (Prado et al., 2008a). Carcass dreessing $(54.7 \%)$ is close to rates for crossbred bulls finished in feedlot and fed on diets with $12 \% \mathrm{CP}$ and $74 \% \mathrm{TDN}$ (Rotta et al., 2009a).

Table 3 - Carcass characteristics of crossbred bulls fed on corn silage cuttings at different heights, with or without inoculants

\begin{tabular}{|c|c|c|c|c|c|c|c|}
\hline \multirow[t]{2}{*}{ Parameters } & \multicolumn{2}{|c|}{ Inoculant } & \multirow[b]{2}{*}{$\mathrm{P}$} & \multicolumn{2}{|c|}{ Height } & \multirow[b]{2}{*}{$\mathrm{P}$} & \multirow{2}{*}{$\frac{\text { Ino } * \times \text { Height }}{\mathrm{P}}$} \\
\hline & With & Without & & Low & High & & \\
\hline WWC, kg & $272.1 \pm 5.559$ & $278.8 \pm 5.559$ & 0.396 & $275.6 \pm 5.559$ & $275.3 \pm 5.559$ & 0.964 & 0.208 \\
\hline COF, scores & $11.9 \pm 0.264$ & $12.7 \pm 0.264$ & 0.054 & $12.1 \pm 0.264$ & $12.6 \pm 0.264$ & 0.191 & 0.324 \\
\hline $\mathrm{LC}, \mathrm{cm}$ & $140.6 \pm 1.017$ & $141.6 \pm 1.017$ & 0.517 & $140.9 \pm 1.017$ & $141.2 \pm 1.017$ & 0.880 & 0.130 \\
\hline $\mathrm{LL}, \mathrm{cm}$ & $73.5 \pm 0.608$ & $73.4 \pm 0.608$ & 0.868 & $73.7 \pm 0.608$ & $73.2 \pm 0.608$ & 0.561 & 0.133 \\
\hline $\mathrm{LM}, \mathrm{cm}^{2}$ & $62.0 \pm 1.676$ & $63.0 \pm 1.676$ & 0.676 & $62.2 \pm 1.676$ & $62.8 \pm 1.676$ & 0.794 & 0.137 \\
\hline MAR, scores & $5.2 \pm 0.414$ & $6.2 \pm 0.414$ & 0.121 & $6.1 \pm 0.414$ & $5.4 \pm 0.414$ & 0.250 & 0.598 \\
\hline TEX, scores & $4.4 \pm 0.138$ & $4.2 \pm 0.138$ & 0.526 & $4.2 \pm 0.138$ & $4.4 \pm 0.138$ & 0.526 & 0.526 \\
\hline Color, scores & $3.9 \pm 0.172$ & $3.9 \pm 0.172$ & 1.000 & $4.1 \pm 0.172$ & $3.8 \pm 0.172$ & 0.313 & 0.611 \\
\hline $\mathrm{pH}$ & $5.9 \pm 0.095$ & $5.9 \pm 0.095$ & 0.746 & $5.9 \pm 0.095$ & $5.9 \pm 0.095$ & 0.548 & 0.159 \\
\hline Muscle, \% & $62.5 \pm 0.740$ & $63.4 \pm 0.740$ & 0.430 & $63.0 \pm 0.740$ & $62.9 \pm 0.740$ & 0.877 & 0.397 \\
\hline
\end{tabular}

$\mathrm{WWC}=$ hot carcass weight; $\mathrm{DWC}=$ hot carcass dressing; $\mathrm{COF}=$ conformation; $\mathrm{LC}=$ length of carcass; $\mathrm{LL}=$ length of leg; $\mathrm{CT}=$ cushion thickness; $\mathrm{FT}=$ fat thickness; $\mathrm{LM}=$ Longissimus muscle; $\mathrm{MAR}=$ marbling; $\mathrm{TEX}=$ texture

*Inoculant. 
No difference $(\mathrm{P}>0.05)$ was reported between silage cutting height coupled to silage inoculants on carcass conformation, length of carcass, length of leg and sirloin thickness. Conformation is a subjective evaluation and represents carcass muscularity especially on the animal hindquarter, where, except for the fat cover, high commercial cuts are available. Mean conformation data reached 12.3 scores which were rated 'good' in the score scale by Müller (1980). Abrahão et al. (2005) reported mean rates of 12.3 scores for carcasses of crossbred bulls finished in feedlot and fed on a replacement of corn by manioc residues at different levels. Good conformation is partly due to the genetic degree of the animals (F1-1/2 Angus vs. $1 / 2$ Nellore) and their final high weight at the end of the experiment.

Mean carcass length, leg length and cushion thickness rates were respectively 141,73 and $24 \mathrm{~cm}$. Neumann et al. (2008) failed to register any difference for the same factors for crossbred bulls finished in feedlot and fed on corn silage harvested at heights 15 or $38 \mathrm{~cm}$. The characteristics above are only slightly modified through nutritional management. In fact, they are mainly modified by different genetic groups used by Rotta et al. (2009a).

No difference $(\mathrm{P}>0.05)$ in the fat thickness and in the Longissimus muscle, respectively with mean $4.17 \mathrm{~mm}$ and $62.5 \mathrm{~cm}^{2}$, was extant for different silage cutting heights coupled to inoculants. Longissimus muscle is directly related to carcass weight (Costa et al., 2002). Since there was no difference in carcass weight, REA values were unaltered. Mean Longissimus muscle rates comply with those required by abattoirs. According to Costa et al. (2002), fat thickness should be between 3 and $6 \mathrm{~mm}$ in the carcass. Lower rates jeopardize the carcass, since it fails to protect adequately the external muscles and gives them a dark color during the cold period. Higher rates mean liabilities to the beef cattle producer and fat excess is eliminated in carcass trimming in the abattoir. Lopes et al. (2008) used meta-analysis methodology in more than sixtyfive thousand animals of different genetic groups, finishing systems and gender in different countries with regard to these two factors. Results were similar to those in current trial, with mean Longissimus muscle and fat thickness rates at $63.5 \mathrm{~cm}^{2}$ and $4.2 \mathrm{~mm}$, respectively.

Color rates, mean 3.94 scores, were not different when cutting height and inoculants are taken into consideration. According to classification by Müller (1980), the color ranges from red to slightly dark red, which is well accepted by consumers. Since beef color is one of the main aspects observed by consumers, darker red beef related either to inadequate pre-finishing management, or to old animal carcasses or to bad beef conservation is less accepted (Müller, 1987).
Beef texture, mean 4.31 scores, was similar for the different diets $(\mathrm{P}>0.05)$ and rated 'very good' according to the score scale by Müller (1980). Beef texture is the beef surface granulation comprising a set of muscle fibers grouped in fascicles encapsulated by a fine layer of connective tissue, called the perimysium. Older cattle with high zebu genetic participation have a rougher texture than younger animals of taurus genetic origin. In fact, the latter is associated with beef tenderness.

Marbling, mean 5.72 scores, was not influenced by cutting height and inoculants $(\mathrm{P}>0.05)$ and was rated 'light'. According to Costa et al. (2002), marbling is an important characteristic closely related to sensorial factors which may be perceived by consumers. Low scores in the crossbred bulls may be due to high zebu genetic participation (F1 $1 / 2$ Nellore vs. $1 / 2$ Angus) in which Bos indicus animals produce low marbling rates when compared with animals with a higher genetic participation in the Bos taurus genotype. Low marbling scores may also be due to the animal category by which bulls are prone to produce less fat in this region when compared with steers (Vaz \& Restle, 2000).

Bone, muscle and fat percentages did not differ $(\mathrm{P}>0.05)$ when different diets were provided. In fact, data in current trial are similar to those by Abrahão et al. (2005) and Maggioni et al. (2009) with research on crossbred bulls, finished in feedlot, within the age gap as those described in the current essay. Rates tend to change according to animal chronological age, since young steers have a higher bone participation in their carcass. As maturity degree increases, an increase in muscle growth also occurs. As the animals grow older, a decrease in muscle tissues and an increase in fat tissue deposits occur if energy consumption is higher than that required by the animal.

Corn silage cutting height ( 25 or $45 \mathrm{~cm})$ coupled to inoculants did not influence rates of moisture, ash, crude protein, total lipids or total cholesterol of the Longissimus muscle of crossbred bulls finished in feedlot (Table 4).

Mean rates of moisture and ashes of the Longissimus muscle were respectively 73.7 and $0.89 \%$. Similar rates were reported by Maggioni et al. (2009) in a trial with crossbred bulls in feedlot, with similar weight and age as those of the present experiment. Ducatti et al. (2009) also registered similar rates in young Purunã steers finished in feedlot and slaughtered at the same age ( 24 months). Feed only slightly affected moisture and ash rates (Aricetti etal., 2008; Prado et al., 2008a; Rotta et al., 2009b). In fact, changes in moisture and ash rates are related to the percentage of lipids in the Longissimus muscle (Prado et al., 2008a; b). As a rule, when lipid rates increase, there is a decrease in high rates of moisture and ashes, since fat has low moisture and ash levels. 
Table 4 - Chemical composition of the Longissimus muscle of crossbred bulls fed on corn silage cutting at different heights, with or without inoculants

\begin{tabular}{|c|c|c|c|c|c|c|c|}
\hline \multirow[t]{2}{*}{ Parameters } & \multicolumn{2}{|c|}{ Inoculant } & \multirow[b]{2}{*}{$\mathrm{P}$} & \multicolumn{2}{|c|}{ Height } & \multirow[b]{2}{*}{$\mathrm{P}$} & \multirow{2}{*}{$\frac{\text { Ino } * \times \text { Height }}{\mathrm{P}}$} \\
\hline & Without & With & & Low & High & & \\
\hline Moisture, \% & $73.7 \pm 0.376$ & $73.8 \pm 0.376$ & 0.869 & $73.4 \pm 0.376$ & $74.0 \pm 0.376$ & 0.249 & 0.037 \\
\hline Ashes, \% & $0.9 \pm 0.021$ & $0.9 \pm 0.021$ & 0.448 & $0.9 \pm 0.021$ & $0.9 \pm 0.021$ & 0.125 & 0.065 \\
\hline $\mathrm{CP}, \%$ & $22.1 \pm 0.329$ & $22.1 \pm 0.329$ & 0.952 & $22.4 \pm 0.329$ & $21.9 \pm 0.329$ & 0.295 & 0.022 \\
\hline TL, $\%$ & $1.6 \pm 0.146$ & $1.5 \pm 0.146$ & 0.923 & $1.7 \pm 0.146$ & $1.6 \pm 0.146$ & 0.769 & 0.871 \\
\hline CHOL, mg & $37.9 \pm 0.156$ & $37.3 \pm 0.156$ & 0.988 & $37.3 \pm 0.156$ & $37.9 \pm 0.156$ & 0.926 & 0.005 \\
\hline
\end{tabular}

$\mathrm{CP}=$ crude protein $; \mathrm{TL}=$ total lipids $; \mathrm{CHOL}=$ cholesterol in $\mathrm{mg} / 100 \mathrm{~g}$ of muscle

*Inoculant.

Mean percentage of $\mathrm{CP}$ in diets was similar to that reported by Aricetti et al. (2008), Prado et al. (2008b, c, d) and Maggioni et al. (2009). However, Rotta et al. (2009b) in their review on the factors that modify the chemical composition of the steers Longissimus muscle showed that CP levels were close to $24 \%$. CP rates in the Longissimus muscle of steers in general vary only slightly when diet is taken into account (Webb, 2006).

Total lipids percentage, mean $1.6 \%$ in the Longissimus muscle was not affected ( $\mathrm{P}>0.05)$ by cutting height or inoculants. Maggioni et al. (2009) reported high rates in crossbred steers in feedlot within the age bracket as that of the animals in current trial and fed on sorghum silage (44\%) and concentrates $(56 \%)$. Rates, which are low for the category of such animals finished in feedlot and fed on high energy levels, may be partly due to age of steer at slaughter (20 months old). Animals slaughtered at an early age usually have a lower percentage of total lipids in the Longissimus muscle (Aricetti et al., 2008; Prado et al., 2008b). Similarly, the gender (bulls) favors lower fat deposits in the muscle due to the steroid hormones which determine higher muscle tissue deposits (Lee et al., 1990).

Cutting height of corn silage and the use of inoculants in silaging did not influence $(\mathrm{P}>0.05)$ total cholesterol rate in the Longissimus muscle. Since mean rate amounted to $37.6 \mathrm{mg}$ of total cholesterol/100 $\mathrm{g}$ of beef, the rate aforementioned is normal with regard to cholesterol rates in the literature (Rotta et al. 2009b). Slaughtered young steers provide total cholesterol rates ranging between 30 and $45 \mathrm{mg} / 100 \mathrm{~g}$ of beef (Prado et al., 2009a; Rotta et al., 2009b). According to Saucier (1999), rates over $50 \mathrm{mg} / 100 \mathrm{~g}$ of beef are unhealthy for human intake. Consumption of excessive cholesterol and other factors, such as stress, lack of physical exercises, smoking and hormonal imbalance, are linked to heart conditions and biliary calculi. However, cholesterol should not be totally removed from human diet since it is the forerunner of steroid hormones, sexual hormones, biliary acids and vitamin D. The latter may only be found in animal-derived products such as beef and yolk.
No influence $(\mathrm{P}>0.05)$ occurred between the different diets (cutting height of silage coupled to inoculants) on the percentage of fatty acids in the Longissimus muscle of steers finished in feedlot (Table 5).

Palmitic (16:0), stearic (18:0), oleic (18:1 $n$-9) and linoleic (18:2 n-6) acids are the main fatty acids in the steers' Longissimus muscle, which, in all, comprise more than $90 \%$ of fatty acids. These results comply with data obtained by Prado et al. (2008b) and Rotta et al. (2009a).

Mean percentages of the myristic (14:0) and palmitic (16:0) saturated fatty acids in steers were respectively 2.14 and $25.96 \%$. Prado et al. (2008b) reported similar rates in crossbred bulls finished in feedlot and fed on corn silage $(50 \%)$ and concentrate $(50 \%)$. The two abovementioned fatty acids are hypercholesterolemic factors and cause an increase in low density lipoprotein (LDL), which provokes coronary diseases. Stearic acid (18:0) participates at an average of $18 \%$ of fatty acids in the Longissimus muscle of steers. Corn cutting height and inoculants in ensilage did not alter $(\mathrm{P}>0.05)$ the acid participation in steers with regard to different diets. Stearic acid is a saturated fatty acid with an 18 carbon atom chain without double links. Although saturated fat of steer beef may contribute significantly to a rise in cholesterol rates in humans (Bessa, 1999), stearicrich fats do not have such characteristics, since they are classified as neutral fatty acids without the harmful effects to the heart as other saturated fatty ones.

Oleic fatty acid has an average of more than $42 \%$ of total fatty acids. Similar rates were registered by Ducatti et al. (2009; Prado et al., 2009b) in crossbred cattle finished in feedlot. Oleic acid reduces the concentration of LDL cholesterol and raises the concentration of HDL cholesterol in the blood. This fatty acid is associated with decrease of cardiovascular risks. Among the unsaturated fatty acids, the linoleic (18:2n-6) and the $\alpha$-linolenic (18:3n-3) acids are classified as essential fatty acids. Their intake occurs in feeding, since mammal cells are unable to synthesize them. Mean rates of the two fatty acids were respectively 4.10 and $0.46 \%$. In their trials on Purunã cattle finished in feedlot, 
Prado et al. (2009b) obtained rates close to those in the present experiment.

Mean percentage of conjugated linoleic acid (18:2 cis 9 , trans 11) of the Longissimus muscle of steers fed on corn silage cutting at different heights was $0.27 \%$. Similar results were reported by Rotta et al. (2009b), who experimented with crossbred steers ( $1 / 2$ Nellore $v s .1 / 2$ Angus) finished in feedlot and by Ducatti et al. (2009), who employed crossed steers in feedlot. The conjugated linoleic acid has positive effects on human health, as reported by Schmid et al. (2006), among which its beneficent effects against cancer, cardiovascular diseases, diabetes and the immune system should be mentioned. Research should thus focus on raising conjugated linoleic acid concentration rates in beef.

The percentage of saturated fatty acids was not altered $(\mathrm{P}>0.05)$ by cutting height and inoculants in ensilage (Table 6). Mean percentage of saturated fatty acids was
$47 \%$ of all fatty acids. Abrahão et al. (2008) reported similar rates when evaluating different genetic groups finished in feedlot. Intake of saturated fatty acids is associated with various types of cancer and coronary diseases (Wood, 2003). However, in spite of the high proportion of saturated fatty acids, most is composed of neutral stearic acid, which does not alter blood cholesterol (Bessa, 1999).

Cut height and inoculants failed to alter $(\mathrm{P}>0.05)$ the percentages of mono-unsaturated fatty acids and polyunsaturated fatty acids; mean 46 and 6\%, respectively, of total fatty acids, in the Longissimus muscle of bulls. In their trials with crossbred steers finished in feedlot, Ducatti et al. (2009) did not report any difference in these percentages and registered mean 45.6 and $7 \%$ for mono- and poly-unsaturated fatty acids, respectively.

Experiment results show that the steers beef fat was composed of more than a half of (mono- and poly-)

Table 5 - Composition of fatty acids in the Longissimus muscle of crossbred steers fed on corn silage cuttings at different heights with or without inoculants

\begin{tabular}{|c|c|c|c|c|c|c|c|}
\hline \multirow[t]{2}{*}{ Parameters } & \multicolumn{2}{|c|}{ Inoculant } & \multirow[b]{2}{*}{$\mathrm{P}$} & \multicolumn{2}{|c|}{ Height } & \multirow[b]{2}{*}{$\mathrm{P}$} & \multirow{2}{*}{$\frac{\text { Ino }^{*} \times \text { Height }}{\mathrm{P}}$} \\
\hline & Without & With & & Low & High & & \\
\hline $14: 0$ & $2.1 \pm 0.115$ & $2.2 \pm 0.115$ & 0.755 & $2.2 \pm 0.115$ & $2.1 \pm 0.115$ & 0.703 & 0.234 \\
\hline $14: 1 \quad n-7$ & $0.3 \pm 0.026$ & $0.3 \pm 0.026$ & 0.725 & $0.3 \pm 0.026$ & $0.3 \pm 0.026$ & 0.378 & 0.215 \\
\hline $15: 0$ & $0.3 \pm 0.018$ & $0.3 \pm 0.018$ & 0.980 & $0.2 \pm 0.018$ & $0.3 \pm 0.018$ & 0.196 & 0.047 \\
\hline $16: 0$ & $25.6 \pm 0.512$ & $26.4 \pm 0.512$ & 0.282 & $25.9 \pm 0.512$ & $25.9 \pm 0.512$ & 0.932 & 0.289 \\
\hline $16: 1 \quad n-9$ & $0.2 \pm 0.007$ & $0.2 \pm 0.007$ & 0.120 & $0.2 \pm 0.007$ & $0.2 \pm 0.007$ & 0.120 & 0.028 \\
\hline $16: 1 \quad n-7$ & $2.5 \pm 0.098$ & $2.6 \pm 0.098$ & 0.293 & $2.6 \pm 0.098$ & $2.4 \pm 0.098$ & 0.089 & 0.125 \\
\hline $17: 0$ & $0.8 \pm 0.031$ & $0.8 \pm 0.031$ & 0.673 & $0.7 \pm 0.031$ & $0.8 \pm 0.031$ & 0.053 & 0.289 \\
\hline $17: 1 \quad n-9$ & $0.5 \pm 0.026$ & $0.5 \pm 0.026$ & 0.689 & $0.5 \pm 0.026$ & $0.5 \pm 0.026$ & 0.919 & 0.245 \\
\hline $18: 0$ & $18.3 \pm 0.434$ & $17.8 \pm 0.434$ & 0.410 & $17.2 \pm 0.434$ & $18.8 \pm 0.434$ & 0.017 & 0.178 \\
\hline $18: 1 \quad n-9$ & $42.4 \pm 0.752$ & $41.8 \pm 0.752$ & 0.579 & $42.5 \pm 0.752$ & $41.6 \pm 0.752$ & 0.439 & 0.209 \\
\hline $18: 1 \quad n-7$ & $0.6 \pm 0.081$ & $0.6 \pm 0.081$ & 0.965 & $0.6 \pm 0.081$ & $0.6 \pm 0.081$ & 0.619 & 0.582 \\
\hline $18: 2 n-6$ & $4.0 \pm 0.328$ & $4.1 \pm 0.328$ & 0.817 & $4.2 \pm 0.328$ & $3.9 \pm 0.328$ & 0.538 & 0.129 \\
\hline $18: 3 n-6$ & $0.1 \pm 0.000$ & $0.1 \pm 0.000$ & 0.326 & $0.1 \pm 0.000$ & $0.1 \pm 0.000$ & 0.326 & 0.326 \\
\hline $18: 3 n-3$ & $0.4 \pm 0.036$ & $0.5 \pm 0.036$ & 0.526 & $0.5 \pm 0.036$ & $0.4 \pm 0.036$ & 0.876 & 0.108 \\
\hline $18: 2 c 9, t 11$ & $0.3 \pm 0.016$ & $0.3 \pm 0.016$ & 0.583 & $0.3 \pm 0.016$ & $0.3 \pm 0.016$ & 0.783 & 0.055 \\
\hline $22: 0$ & $0.1 \pm 0.012$ & $0.1 \pm 0.012$ & 0.914 & $0.1 \pm 0.012$ & $0.1 \pm 0.012$ & 0.588 & 0.856 \\
\hline $20: 4 n-6$ & $0.9 \pm 0.104$ & $0.9 \pm 0.104$ & 0.659 & $0.9 \pm 0.104$ & $0.8 \pm 0.104$ & 0.425 & 0.369 \\
\hline $20: 5 n-3$ & $0.3 \pm 0.046$ & $0.3 \pm 0.046$ & 0.909 & $0.3 \pm 0.046$ & $0.3 \pm 0.046$ & 0.909 & 0.664 \\
\hline $22: 4 n-6$ & $0.1 \pm 0.021$ & $0.1 \pm 0.021$ & 0.745 & $0.1 \pm 0.021$ & $0.1 \pm 0.021$ & 0.544 & 0.245 \\
\hline $22: 6 n-3$ & $0.2 \pm 0.085$ & $0.1 \pm 0.085$ & 0.259 & $0.2 \pm 0.085$ & $0.1 \pm 0.085$ & 0.408 & 0.172 \\
\hline
\end{tabular}

Table 6 - Sum of fatty acids of the Longissimus muscle of crossbred steers fed on silage corn cuttings at different heights, with or without to inoculants

\begin{tabular}{|c|c|c|c|c|c|c|c|}
\hline \multirow[t]{2}{*}{ Parameters } & \multicolumn{2}{|c|}{ Inoculant } & \multirow[b]{2}{*}{$\mathrm{P}$} & \multicolumn{2}{|c|}{ Height } & \multirow[b]{2}{*}{$\mathrm{P}$} & \multirow{2}{*}{$\frac{\text { Ino }^{*} \times \text { Heigh }}{\mathrm{P}}$} \\
\hline & Without & With & & Low & High & & \\
\hline SFA & $47.1 \pm 0.821$ & $47.5 \pm 0.821$ & 0.790 & $46.5 \pm 0.821$ & $48.1 \pm 0.821$ & 0.194 & 0.844 \\
\hline MUFA & $46.5 \pm 0.770$ & $46.1 \pm 0.770$ & 0.718 & $46.8 \pm 0.770$ & $45.7 \pm 0.770$ & 0.349 & 0.381 \\
\hline PUSFA & $6.4 \pm 0.502$ & $6.5 \pm 0.502$ & 0.900 & $6.7 \pm 0.502$ & $6.2 \pm 0.502$ & 0.476 & 0.308 \\
\hline$n-3$ & $1.0 \pm 0.130$ & $0.9 \pm 0.130$ & 0.546 & $1.0 \pm 0.130$ & $0.9 \pm 0.130$ & 0.551 & 0.560 \\
\hline$n-6$ & $5.0 \pm 0.420$ & $5.2 \pm 0.420$ & 0.747 & $5.3 \pm 0.420$ & $4.9 \pm 0.420$ & 0.522 & 0.169 \\
\hline PUSFA/SFA & $0.1 \pm 0.012$ & $0.1 \pm 0.012$ & 0.0 .944 & $0.1 \pm 0.012$ & $0.1 \pm 0.012$ & 0.331 & 0.486 \\
\hline$n-6 / n-3$ & $6.0 \pm 0.325$ & $6.3 \pm 0.325$ & 0.570 & $6.3 \pm 0.325$ & $6.1 \pm 0.325$ & 0.624 & 0.142 \\
\hline
\end{tabular}

$\mathrm{SFA}=$ saturated fatty acids; MUFA = mono-unsaturated fatty acids; PUSFA = poly-unsaturated fatty acids; $n-3=$ omega- 3 fatty acids; $n-6=$ omega- 6 fatty acids; PUSFA/SFA = poly-unsaturated fatty acids/saturated fatty acids ratio; $n-6 / n-3=$ omega-3 fatty acids/omega- 6 fatty acids ratio.

*Inoculant. 
unsaturated fatty acids (MUFA and PUSFA) which are healthy to humans. The other half is formed by saturated fatty acids, mostly stearic fatty acid, which is neutral with regard to blood cholesterol rates. Therefore, only $29 \%$ is harmful to human health.

The poly-unsaturated fatty acids/saturated fatty acids ratio, mean rate of 0.14 , also reported by Prado et al. (2009a, b) in Purunã steers finished in feedlot was not altered $(\mathrm{P}>0.05)$ by cutting height and by inoculants. According to the British Health Department (1994), this ratio is expected to be above 0.4 so that food may be beneficent to humans. Low poly-unsaturated fatty acids/saturated fatty acids ratio relation may be partly due to high stearic acid, which is the result of the final product of poly-unsaturated fatty acids ruminal bio-hydrogenation.

Similarly, $n-6 / n-3$ ratio, average 6.18 , failed to show any difference $(\mathrm{P}>0.05)$ between the diets. Maggioni et al. (2009) reported a 6.7 ratio in crossbred steers finished in feedlot. According to the British Health Department (1994), this ratio should be less than four parts of $n-6$ for one part of $n-3$, due to risks in cancer and coronary diseases, which an imbalanced diet produces.

\section{Conclusions}

Corm silage harvested at two different cutting heights (25 and $45 \mathrm{~cm}$ ) does not improve weight gain or carcass characteristics of 20-month-old steers finished in feedlot, with an average daily gain of $1.80 \mathrm{~kg}$. Moreover, the inclusion of enzyme-bacterial inoculants does not improve animal performance or beef quality. Corn cuttings at $45 \mathrm{~cm}$ from the ground and inoculants for better performance of feedlot animals are not necessary for steers fed on a diet composed of $50 \%$ roughage (corn silage) and $50 \%$ concentrate with $12 \%$ crude protein and $74 \%$ total digestible nutrients.

\section{References}

ABRAHÃO, J.J.S.; PRADO, I.N.; PEROTTO, D. et al. Características de carcaças e da carne de tourinhos submetidos a dietas com diferentes níveis de substituição do milho por resíduo úmido da extração da fécula de mandioca. Revista Brasileira de Zootecnia, v.34, n.5, p.1640-1650, 2005

ABRAHÃO, J.J.S.; PRADO, I.N.; MARQUES, J.A. et al. Avaliação da substituição do milho pelo resíduo seco da extração da fécula de mandioca sobre o desempenho de novilhas mestiças confinadas. Revista Brasileira de Zootecnia, v.35, n.2, p. 512-518, 2006 .

ABRAHÃO, J.J.S.; MARQUES, J.A.; MACEDO, L.M.A. et al. Composição química e perfil de ácidos do músculo Longissimus de bovinos de diferentes grupos genéticos terminados em confinamento. Acta Scientiarum.Animal Sciences, v.30, n.4, p.443-449, 2008

AL-HASANI, S.M.; MLAVAC, J.; CARPENTER, M.W. Rapid determination of cholesterol in single and multiconponent prepared foods. Journal American Oil Chemists Society, v.76, p.902-906, 1993

ANUALPEC. Anuário da pecuária brasileira. São Paulo: Instituto FNP, 2009. 360p.

ARICETTI, J.A.; ROTTA, P.P.; PRADO, R.M. et al. Carcass characteristics, chemical composition and fatty acid profile of Longissimus muscle of bulls and steers finished in a pasture systems. Asian Australasian Journal of Animal Science, v.21, n.10, p.1441-1448, 2008.

ASSOCIATION OF OFFICIAL CHEMISTS - AOAC. Official methods of analysis. 14.ed. Arlington, V.A., 1980. 1094p.

BESSA, R.J.B. Revalorização nutricional das gorduras dos ruminantes. In: SYMPOSIUM EUROPEO - ALIMENTACIÓN EN EL SIGLO, 21., 1999, Badajoz. Anais... Badajoz: Colegio Oficial de Veterinarios de Badajoz, 1999. p.283-313.

BLIGH, E.G.; DYER, W.J. A rapid method of total lipid extraction and purification. Canadian Journal of Biochemistry and Physiology, v.37, p.911-917, 1959.

COSTA, E.C.; RESTLE, J.; VAZ, F.N. et al. Características da carcaça de novilhos Red Angus superprecoces abatidos com diferentes pesos. Revista Brasileira de Zootecnia, v.31, n.1, p.119-128, 2002 .

CUNNIFF, P.A. (Ed). Official Methods of Analysis of AOAC International. 16.ed. Arlington: Association of Official Analytical Chemists International, 1998. (CD-ROM).

DEPARTMENT OF HEALTH. Nutritional aspects of cardiovascular disease. Report on Health and Social Subject $\mathrm{n}^{\circ}$. 46. London: Her Majesty's Stationery Office, 1994.

DIAN, P.H.M.; PRADO, I.N.; FUGITA, C.A. et al. Substituição do milho pelo resíduo de fecularia de mandioca sobre o desempenho, digestibilidade e características de carcaça de novilhos confinados. Acta Scientiarum.Animal Sciences, v.31, n.4 p.381-387, 2009.

DUCATTI, T.; PRADO, I.N.; ROTTA P.P. et al. Chemical composition and fatty acid profile in crossbred (Bos taurus vs. Bos indicus) young bulls finished in a feedlot. Asian Australasian Journal of Animal Science, v.22, n.3, p.433-439, 2009.

GIGER-REVERDIN, D.; DUVAUX-PONTER, C.; SAUVANT, D.; MARTIN, O.; PRADO, I.N.; MÜLLER, R. Intrinsic buffering capacity of feedstuffs. Animal Feed Science and Technology, v.96, n.1-2, p.83-102, 2002.

HANKINS, O.G.; HOWE, P.E. Estimation of the composition of beef carcasses and cuts. Washington: Agriculture Department, 1946. 20p. (Technical Bulletin, 926).

INTERNATIONAL ORGANIZATION FOR STANDARDIZATION - ISO. Method ISO 5509. Geneve: ISO, 1978. 6p.

LEE, C.Y.; HENRICKS, D.M.; SKELLEY, G.C. et al. Growth and hormonal response of intact and castrate male cattle to trenbolone acetate and estradiol. Journal of Animal Science, v.68, p.2682-2689, 1990.

LOPES, J.S.; RORATO, P.R.N.; WEBER, T. et al. Meta-análise para características de carcaça de bovinos de diferentes grupos genéticos. Ciência Rural, v.38, p.2278-2284, 2008.

MAGGIONI, D.; MARQUES, J.A.; PEROTTO, D. et al. Bermuda Grass hay or sorghum silage with or without yeast addition on performance and carcass characteristics of crossbred Young bulls finished in feedlot. Asian-Australasian Journal of Animal Science, v.22, n.2, p.206-215, 2009.

MOREIRA, F.B.; SOUZA, N.E.; MATSUSHITA, M. et al. Evaluation of carcass characteristics and meat chemical composition of Bos indicus x Bos taurus crossbred steers finished in pasture systems. Brazilian Archives of Biology and Technology, v.46, n.4, p.609-616, 2003

MÜLLER, L. Normas para avaliação de carcaça e concurso de carcaças de novilhos. 1.ed. Santa Maria: UFSM, 1980. 31p.

MÜLLER, L. Normas para avaliação de carcaças e concurso de carcaça de novilhos 2.ed. Santa Maria: Universidade Federal de Santa Maria, 1987. 31p. 
MÜLlER, L.; MAXON, W.E.; PALMER, A.Z. Evaluación de técnicas para determinar La composición de la canal. In: Memoria de la Associación Latinoamericana de Producción Animal, 1973, Guadalajara. Anais... Guadalajara, 1973.

NATIONAL RESEARCH COUNCIL - NRC. Nutrient requirements of beef cattle. 7.ed. Washington, D.C.: National Academy Press, 2000. 261p.

NEUMANN, M.; MUHLBACH, P.R.F.; NORNBERG, J.L. et al. Efeito do tamanho de partícula e da altura de colheita das plantas de milho (Zea mays L.) para ensilagem na produção do novilho superprecoce. Revista Brasileira de Zootecnia, v.36, n.5, p.1614-1623, 2007.

NEUMANN, M.; RESTle, J.; MUHLBACH, P.R.F. et al. Componentes de rendimento e características da carne e carcaça de novilhos confinados sob efeito do tamanho de partícula e da altura de colheita das plantas de milho na ensilagem. Ciência Rural, v.38, n.2, p.423-431, 2008.

PEROTTO, D.; MOLETTA, J.L.; OLIVEIRA, J.E.P. et al. Feed intake and feed:gain ratio of Charolais, Caracu and reciprocal crossbred males finished in feedlot. Revista Brasileira de Zootecnia, v.29, n.1, p.108-116, 2000.

PRADO, I.N.; LALlO, F.H.; ZEOULA, L.M. et al. Níveis de substituição da silagem de milho pela silagem de resíduo industrial de abacaxi sobre o desempenho de bovinos confinados. Revista Brasileira de Zootecnia, v.32, n.3, p.737-744, 2003.

PRADO, I.N.; ITO, R.H.; PRADO, J.M. et al. The influence of dietary soyabean and linseed on the chemical composition and fatty acid profile of the Longissimus muscle of feedlot-finished bulls. Journal of Animal and Feed Science, v.17, p.307-317, $2008 \mathrm{a}$.

PRADO, I.N.; PRADO, R.M.; ROTTA, P.P. et al. Carcass characteristics and chemical composition of the Longissimus muscle of crossbred bulls (Bos taurus indicus vs. Bos taurus taurus) finished in feedlot. Journal of Animal and Feed Science, v.17, p.295-306, 2008b.

PRADO, I.N.; ROTTA, P.P.; PRADO, R.M. et al. Carcass characteristics and chemical composition of the Longissimus muscle of Purunã and $1 / 2$ Purunã $\times 1 / 2$ Canchin bulls. Asian Australasian Journal of Animal Science, v.21, n.9, p.1296-1302, $2008 \mathrm{c}$.

PRADO, I.N.; ARICETTI, J.A.; ROTTA, P.P. et al. Carcass characteristics, chemical composition and fatty acid profile of the Longissimus muscle of bulls (Bos taurus indicus x Bos taurus taurus) finished in pasture systems. Asian Australasian Journal of Animal Science, v.21, n.10, p.1449-1457, 2008d.
PRADO, J.M.; PRADO, I.N.; VISENTAINER, J.V. et al. The effect of breed on the chemical composition and fatty acid profile of the Longissimus dorsi muscle of Brazilian beef cattle. Journal of Animal and Feed Science, v.18, p.231-240, 2009a.

PRADO, I.N.; MARQUES, J.A.; ROTTA, P.P. et al. Meat quality of the Longissimus muscle of bulls and steers ( $1 \frac{1}{2} \mathrm{Nellore}$ vs $1 / 2$ Simmental) finished in feedlot. Journal of Animal and Feed Science, v.18, p.221-230, 2009b.

REIS, R.A.; RUGGIERI, A.C.; CASAGRANDE, D.R. et al. Suplementação da dieta de bovinos de corte como estratégia do manejo das pastagens. Revista Brasileira de Zootecnia, v.38, n.1, p.147-159, 2009.

RESTLE, J.; NEUMANN, M.; BRONDANI, I.L. et al. Manipulação da altura de corte da planta de milho (Zea mays, L.) para ensilagem, visando a produção do superprecoce. Revista Brasileira de Zootecnia, v.31, n.3, p.1235-1244, 2002.

ROTTA, P.P.; PRADO, R.M.; MOLETTA, J.L. et al. Carcass Characteristics and chemical composition of the Longissimus muscle of Nellore, Caracu and Holstein-friesian bulls finished in a feedlot. Asian Australasian Journal of Animal Sciences, v.22, n.4, p.598-604, 2009a.

ROTTA, P.P.; PRADO, R.M.; PRADO, I.N. et al. The effects of genetic groups, nutrition, finishing systems and gender of Brazilian cattle on carcass characteristics and beef composition and appearance: a review. Asian Australasian Journal of Animal Science, v.22, n.12, p.1718-1734, 2009b.

SAUCIER L. Meat safety: challenges for the future. Nutrition Abstracts and Reviews, v.69, p.705-708. 1999.

SCHMID, A.; COLLOMB, M.; SIEBER, R. et al. Conjugated linoleic acid in meat and meat products: a review. Meat Science, v.73, n.1, p.29-41, 2006.

SILVA, D.J.; QUEIROZ, S.A. Análise de alimentos: métodos químicos e biológicos. Viçosa, MG: UFV, 2002. p.23.

VAZ, F.N.; RESTLE, J. Aspectos qualitativos da carcaça e da carne de machos Hereford, inteiros ou castrados, abatidos aos quatorze meses. Revista Brasileira de Zootecnia, v.29, n.6, p.1894-1901, 2000.

WEBB, E.C. Manipulating beef quality through feeding. South African Journal of Food Science Nutrition, v.7, n.1, p.1-24, 2006.

WOOD, J.D.; RICHARDSON, R.I.; NUTE, G.R. et al. Effects of fatty acids on meat quality: a review. Meat Science, v.66, n.1, p.21-32, 2003

WU, Z.; ROTH, G. Considerations in managing cutting height of corn silage. Department of Dairy and Animal Science. The Pennsylvania State University, DAS 03-72, p.7. Available at: <www.das.psu.edu>. Accessed on: July 26, 2006. 